\title{
PERKEMBANGAN PERIKANAN TUNA DI PELABUHANRATU
}

\author{
I Gede Sedana Mertha", Moch. Nurhuda", dan Ahmad Nasrullah")
}

\begin{abstract}
ABSTRAK
Perikanan tuna di Pelabuhanratu berkembang sejak lama, menggunakan alat-alat tangkap payang dan gill net. Mulai tahun 2001 mulai masuk kapal-kapal tuna long line dari Cilacap untuk membongkar hasil tangkapan, kemudian dengan truk dibawa ke Muara Baru, Jakarta. Kemudian sejak tahun 2004, PT. Sari Samudera Utama yang berdomisili di Benoa, mulai memindahkan kapalkapal long line tipe $30 \mathrm{GT}$. Rencana akan ada 30 kapal yang akan dipindahkan ke Pelabuhanratu. Pada tahun yang sama mulai beroperasi kapal-kapal hand line dari Sulawesi Selatan. Direncanakan akan ada 60 handliner yang beroperasi di perairan Selatan Pelabuhanratu dengan menggunakan alat bantu rumpon laut dalam. Pada bulan-bulan Maret, April, dan Mei 2005 banyak tertangkap ikanikan madidihang yuwana dengan hand line yaitu masing-masing 98,$8 ; 98,2$; dan $100 \%$ pada bulanbulan Maret, April, dan Mei 2005. Hubungan panjang bobot yang diperoleh adalah isometris, baik untuk bulan Maret, April, maupun Mei 2005.
\end{abstract}

KATA KUNCI: perkembangan, perikanan pancing ulur, Pelabuhanratu

ABSTRACT: The development of tuna fishery of Pelabuhan Ratu. By: I. Gede Sedana
Merta, Moch. Nurhuda, and Ahmad Nasrullah

Tuna fishery in Pelabuhanratu has been developing since many years ago, mainly using traditional gears such as Danish seine and gill net. Started in 2001 some tuna longline boats based in Cilacap, unloading their catches at Pelabuhanratu Nusantara Fishing Port. PT. Sani Segara Utama located at Benoa Port started to move to Pelabuhanratu. This company is planning to move 30 boats of its feets to this place. In the same year, Kooperasi Anak Nelayan at Pelabuhanratu has invited 8 of handline boat from Sulawesi, to operate in this waters associated with deep sea FAD. Koperasi Anak Nelayan is planning to develop the handine fishery further by inviting 60 handline boats from South Sulawesi. It was observed in March, April, and May 2005 that high percentage of juveniles of yellowfin tuna ( $<84 \mathrm{~cm} F L$ ) was caught by handline, i.e., 98.8; 98.2; and 100\% respectively. Length weight relationships obtained for yellowfin tuna caught in March, April dan May 2005 were isometric. It means that the growth of yellowfin tuna in weight is proportional to its cubic lengths.

KEYWORDS: tuna fishery, development, Pelabuhanratu

\section{PENDAHULUAN}

Tuna merupakan komoditas ekspor penting setelah udang. Daerah-daerah penangkapan tuna yang penting di Indonesia terutama di perairan kawasah timur Indonesia seperti wilayah pengelolaan perikanan Selat Makassar dan Laut Flores, wilayah pengelolaan perikanan Laut Banda, wilayah pengelolaan perikanan Teluk Tomini dan Laut Maluku, dan wilayah pengelolaan perikanan Sulawesi Utara dan Samudra Pasifik, sedang di perairan kawasan barat Indonesia terutama di wilayah pengelolaan perikanan Samudra Hindia.

Di Samudra Hindia ada 2 jenis perikanan tuna, yaitu tuna industri dan artisanal. Eksploitasi tuna skala industri terutama menggunakan alat tangkap tuna long line, untuk menangkap ikan-ikan tuna besar pada kedalaman di atas, dan di bawah

\footnotetext{
T Peneliti pada Balai Riset Perikanan Laut, Muara Baru-Jakarta

- Mahasiswa pada Sekolah Tinggi Perikanan, Jakarta
}

lapisan thermoklin (100 sampai dengan $300 \mathrm{~m}$ ). Tuna long line berkembang di ZEEI Samudra Hindia sejak tahun 1972, sejak didirikan PT. (Persero) Perikanan Samodra Besar (Simorangkir, 2000; 2003). PT. Perikanan Samodera Besar mulai beroperasi menggunakan 3 buah kapal pada tahun 1972, kemudian menjadi 18 buah tahun 1975 lalu menjadi 21 buah tahun 1981. Kemudian jumlah perusahaan bertambah terus dan jumlah kapal juga bertambah, yang pada tahun 2001 menjadi 618 buah. Kapal-kapal tuna long line di samping berbasis di Benoa, juga berbasis di Cilacap dan Muara Baru (Jakarta).

Untuk menangkap tuna besar, selain dengan tuna long line digunakan juga alat tangkap pancing ulur, yang beroperasi di sekitar rumpon laut dalam (Filipina: payaos). Di kawasan timur Indonesia alat ini berkembang di beberapa daerah antara laín, 
Sulawesi Utara, Teluk Tomini, Laut Maluku, dan Selat Makassar. Sejak mulai beroperasi perusahaan pukat cincin joint venture di Sulawesi Utara, berkembang alat tangkap pancing ulur tipe Filipina yang disebut pumpboat. Alat ini menggunakan jukung motor yang besar, yang daspat beroperasi sampai dengan 2 minggu atau lebih. Jumlah pumpboat yang beroperasi di perairan Sulawesi utara dan sekitar diduga lebih dari 2.000 unit. Jenis pancing ulur lain yang beroperasi di Sulawesi utara dan sekitar adalah samoboat dan pelang tuna. Samoboat menggunakan perahu motor, sedangkan pelang tuna menggunakan jukung bermotor, dan terutama menggunakan alat pancing layang-layang. Jenis armada pancing ulur yang mulai beroperasi di perairan selatan Pelabuhan Ratu adalah samoboat.

Jenis-jenis alat tangkap perikanan tuna artisanal di Samudera Hindia adalah, gill net, payang tonda, dan pukat cincin. Di Pelabuhan Ratu terutama payang dan gill net. Gill net dalam operasi digabung dengan rawai untuk menangkap cucut.

Di perairan Nusa Tenggara Timur (Laut Flores) yang dekat dengan Samudera Hindia berkembang juga pancing ulur yang diasosiasikan dengan berkembang perikanan huhate yang menggunakan rumpon (Barus \& Badrudin, 1992). Di Samudera Hindia, alat tangkap pancing ulur mulai berkembang di perairan Selatan Malang (Sendang Biru) sejak tahun 1990-an. Alat ini dioperasikan oleh nelayan-nelayan dari Sulawesi Selatan. Saat ini diduga ada sekitar 200 unit armada hand line yang beroperasi di selatan Sendang Biru, di mana 4 sampai dengan 5 alat beroperasi pada sebuah rumpon

\section{BAHAN DAN METODE}

\section{Bahan}

Data dikumpulkan di Pelabuhan Perikanan Nusantara Pelabuhan Ratu pada bulan Maret, April, dan Mei 2005). Data primer yang dikumpulkan adalah komposisi jenis, ukuran panjang, dan bobot ikan yang ditangkap. Data sekunder dikumpulkan dari Pelabuhan Perikanan Nusantara Pelabuhan Ratu dan dari Dinas Perikanan Cabang Pelabuhan Ratu, yang meliputi jenis-jenis ikan tuna yang tertangkap dan jenis-jenis alat tangkap yang digunakan.

\section{Metode}

Panjang ikan diukur menggunakan pita pengukur dengan ketepatan $0,5 \mathrm{~cm}$ dan bobot ikan diukur dengan timbangan pegas dengan ketepatan
$50 \mathrm{~g}$. Tidak dilakukan penentuan jenis kelamin dari ikan-ikan yang diukur. Data panjang dan bobot dikelompokan per bulan, yaitu untuk bulan Maret April, dan Mei 2005.

Bobot ikan dalam suatu bagian (stanza) dari hidup bervariasi menurut pangkat tertentu dari panjang, yaitu yang dapat dikatakan dengan rumus berikut (Ricker, 1973; 1975):

$$
W=a^{*} L^{b}
$$

di mana:

$$
\begin{aligned}
\mathrm{W} & =\text { bobot ikan }(\mathrm{g}) \\
\mathrm{L} & =\text { panjang cagak ikan }(\mathrm{cm}) \\
\mathrm{a} \text { dan } \mathrm{b}= & \text { konstanta, atau } \\
& \text { Ramakrishnaiah }(1972): \\
\mathrm{a} & =\text { initial growth index } \\
\mathrm{b} & =
\end{aligned}
$$

Rumus tersebut paling sesuai diterapkan pada ikan-ikan individual, yang diukur panjang dan ditimbang bobot secara berkesinambungan selama hidup (Ricker, 1975).

\section{HASIL DAN BAHASAN}

\section{Perkembangan Perikanan Tuna di Pelabuhan Ratu}

\section{Jenis-jenis ikan yang tertangkap}

Dalam statistik perikanan Indonesia, jenis-jenis ikan tuna dan paruh panjang yang tertangkap dikelompokan ke dalam 3 kelompok, yaitu tuna, cakalang, dan tongkol. Jenis-jenis ikan tuna yang tertangkap di Samudera Hindia adalah ikan madidihang (Thunnus albacares, yellow fin tuna), tuna mata besar (Thunnus obesus, big eye tuna), tuna sirip biru selatan (Thunnus maccoyii, southern blue fin tuna), albakora (Thunnus alalunga, albacore), dan tongkol abu-abu (Thunnus tonggol, long tail tuna), sedangkan jenis-jenis ikan paruh panjang (billfishes) yang tertangkap di Samudera Hindia adalah ikan layaran (Istiophorus platypterus, Indo-Pacific sailfish), ikan pedang (Xiphias gladius, swordfish), setuhuk hitam (Makaira indica, black marlin), setuhuk biru (Makaira mazara, blue marlin), setuhuk loreng (Tetrapturus audax, striped marlin) dan ikan tumbuk (Tetrapturus angustirostris, shortbill spearfish). Ikan-ikan tuna dan paruh panjang dalam statistik perikanan Indonesia masuk ke dalam kelompok tuna. Kelompok ke-2 adalah kelompok cakalang, yang hanya terdiri atas ikan cakalang (Katsuwonus pelamis, skipjack), sedangkan kelompok yang ke-3 adalah kelompok tongkol, yang terdiri atas como (Euthynnus affinis, eastern little tuna), deho (Auxis thazard, frigate 
tuna), lisong (Auxis rochei, bullet tuna), kenyar (Sarda orientalis, striped bonito), slengseng (Scomber australasicus, spoted chub mackerel), dan tongkol sirara atau tongkol gigi anjaing (Gymnosarda unicolor, dogtooth tuna).

Sejak tahun 2005, dalam statistik perikanan lebih banyak jenis-jenis ikan ekonomis penting yang dimasukan. Untuk jenis-jenis ikan tuna dan paruh panjang, semua masuk ke dalam statistik perikanan. Menurut ketentuan-ketentuan di dalam pengelolaan perikanan tuna secara regional, pengkajian stok, dan pengelolaan didasarkan pada spesies, tidak berdasarkan pada kelompok spesies.

Dalam statistik produksi di Pelabuhan Perikanan Nusantara Pelabuhan. Ratu pada tahun-tahun sebelum (2002) tercatat tuna, cakalang, tongkol, layaran (sailfish, Istiophorus platypterus), pedangpedang (swordfish, Xiphias gradius), dan jangilus (marlin), tuna dipisahkan menjadi tuna mata besar (big eye tuna, Thunnus obesus), albakor (albacore, Thunnus alalunga) dan madidihang (yellow fin tuna, Thunnus albacares). Mulai tahun ini juga tongkol dipisah-pisahkan menjadi tongkol abu-abu (long tail tuna, Thunnus tonggol), tongkol banyar (frigate tuna, Auxis thazard), tongkol lisong (bullet tuna, Auxis rochei), dan tongkol kekek (eastern little tuna, Euthynnus affinis).

\section{Perkembangan produksi}

Perkembangan produksi ikan-ikan tuna (tuna cakalang, dan tongkol) dalam periode tahun 1992 sampai dengan 2004, disajikan pada Gambar 1. Produksi yang tertinggi adalah cakalang, kemudian tongkol, lalu tuna. Pada gambar terlihat bahwa produksi ikan-ikan tuna, cakalang, dan tongkol sejak tahun 1992 sangat berfluktuasi. Penurunan produksi yang mencolok terjadi sejak 1996 atau 1997 sampai dengan tahun 2001. Produksi tuna, cakalang, dan tongkol kemudian sejak tahun 2002 terus naik. Produksi tuna naik paling tajam, dan ini kemungkinan disebabkan karena banyak kapalkapal tuna long line dari Cilacap yang mendaratkan hasil tangkapan di Pelabuhan Ratu, untuk memperdekat jarak ke Jakarta, baik ke Muara Baru maupun ke Bandara Sukarno-Hatta.

Ikan-ikan paruh panjang yang tertangkap terutama adalah ikan layaran (Istiophorus platypterus, Indo-Pacific sailfish), meskipun jenisjenis ikan paruh panjang lain yang sering tertangkap seperti, ikan pedang (Xiphias gladius, swordfish), Istiophorus angustirostris, shortbill spearfish) dan jangilus (marlin atau setuhuk), yang belum teridentifikasi secara jelas jenis-jenis (setuhuk hitam, biru, dan loreng). Di dalam laporan tahunan jenis-jenis ikan paruh panjang yang

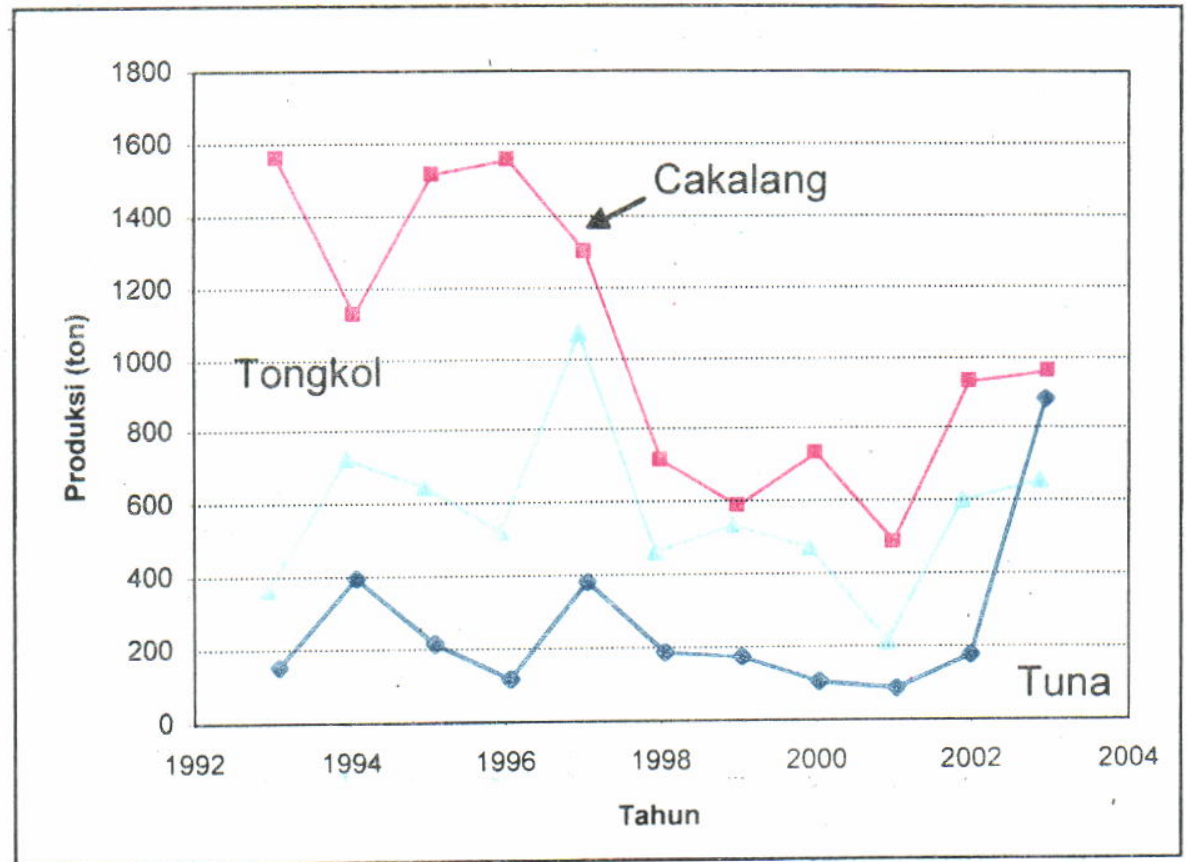

Gambar 1. Perkembangan produksi ikan-ikan tuna, cakalang, dan tongkol dalam periode tahun 1992 sampai dengan 2004 (ton). Sumber: Pelabuhan Perikanan Nusantara Pelabuhan Ratu

Figure 1. The development of tuna, skipjack, and tuna like fishes production in the periode of 1992 to 2004 (tons).

Source: Pelabuhan Ratu Nusantara Fishing Port 
tercatat hanya layaran (sailfish) dan jangilus (marlin atau setuhuk). Sejak tahun 2003, statistik produksi Pelabuhan Perikanan Nusantara Pelabuhan Ratu telah memisahkan tuna menjadi madidihang, mata besar, dan albakora. Produksi bulanan ikan tuna di Pelabuhan Ratu pada tahun 2003 yang tercatat di Pelabuhan Perikanan Nusantara Pelabuhan Ratu disajikan pada Gambar 2.

Produksi madidihang pada bulan Pebruari dan Maret tidak ada. Produksi bulanan (10 bulan) berkisar antara 1,2 sampai dengan 48,3 ton dengan rata-rata 17,8 ton per bulan. Produksi mata besar baru tercatat mulai bulan Mei ( 8 bulan), berkisar antara 0,9 sampai dengan 43,3 ton dengan rata-rata 8,7 ton per bulan. Produkśi total albakor pada tahun 2003 (657.7 ton), berkisar antara 0,5 sampai dengan 310,0 ton dengan ratarata 54.805 ton. Perkembangan produksi ikan tuna bulanan disajikan dalam Tabel 1 .

Produksi bulanan ikan tuna di Pelabuhan Ratu sangat berfluktuasi. Produksi rata-rata setiap tahun dari tahun 1996 sampai dengan 2002 di bawah 40 ton, sedangkan produksi pada tahun 2003 rata-rata hampir 2 kali lipat. Sebelum tahun 2001, produksi tuna berasal terutama dari alat-alat tangkap payang, rata-rata 73 payang per tahun dan gill net rata-rata 177 gill net per tahun Tabel 2. Kemudian pada tahun 2001 alat-alat tangkap yang menangkap tuna bukan payang dan gill net, tetapi juga long line. Kapal-kapal tuna long line yang mendaratkan hasil tangkapan di Pelabuhan Ratu pada umumnya berasal dari Cilacap (Tabel 2).

\section{Perkembangan upaya}

Alat tangkap utama yang digunakan untuk menangkap ikan tuna, cakalang, dan tongkol di Pelabuhan Ratu adalah payang dan gill net. Alat tangkap gill net dikombinasikan dengan rawai untuk menangkap cucut. Alat-alat ini beroperasi ke luar perairan Pelabuhan Ratu, arah ke timur atau ke barat sampai dengan Selat Sunda, dan 1 trip mencapai 10 sampai dengan 14 hari. Payang dioperasikan hanya di dalam teluk, trip harian, dan pagi berangkat sore pulang. Alat tangkap pukat cincin pada waktu-waktu tertentu datang dari Binuangeun, terutama untuk menangkap ikan pelagis kecil dan tongkol.

Sejak tahun 2001 banyak kapal-kapal tuna long line dari Cilacap masuk ke Pelabuhan Perikanan Nusantara Pelabuhan Ratu untuk membongkar hasil tangkapan. Pada tahun 2001 rata-rata jumlah kapal tuna long line dari Cilacap yang mendaratkan hasil tangkapan di Pelabuhanratu adalah rata-rata 22 kapal (5 sampai dengan 90 kapal) per bulan. Pada tahun 2003 kapal-kapal tuna long line yang masuk Pelabuhan Perikanan Nusantara Pelabuhanratu rata-rata 14 kapal (4 sampai dengan 27 kapal) per bulan. Tahun 2004 PT. Sari Segara

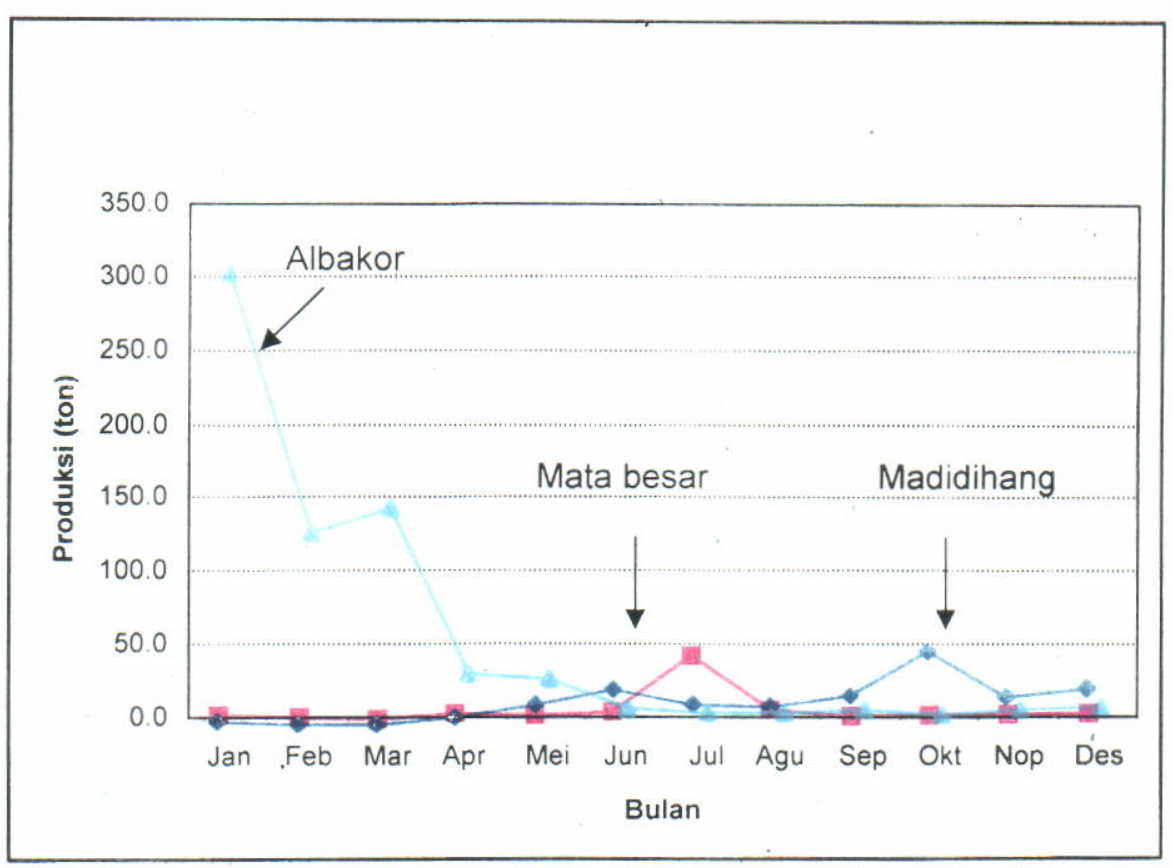

Gambar 2. Perkembangan produksi bulanan ikan albakora, tuna mata besar, dan madidihang di Pelabuhan Ratu, tahun 2003.

Figure 2. The development of monthly production of albacore, big eye, and yellow fin tuna in Pelabuhan Ratu, 2003. 
Tabel 1. Perkembangan produksi ikan tuna bulanan (ton) yang didaratkan di Pelabuhan Perikanan Nusantara Pelabuhan Ratu, tahun 1996 sampai dengan 2003

Table 1. The development of monthly tuna production (ton) landed at Pelabuhan Perikanan Nusantara Pelabuhan Ratu, 1996 to 2003

\begin{tabular}{|c|c|c|c|c|c|c|c|c|}
\hline \multirow{2}{*}{ Bulan } & \multicolumn{8}{|c|}{ Tahun } \\
\hline & 1996 & 1997 & 1998 & 1999 & 2000 & 2001 & $2002^{*}$ & 2003 \\
\hline Januari & 10,6 & 13,6 & 18,5 & 12,8 & 1,0 & 1,8 & 3,5 & $311,1(2)$ \\
\hline Pebruari & 11,0 & 6,2 & 13,7 & 11,0 & 6,6 & 5,4 & 1,3 & $127,4(1)$ \\
\hline Maret & 14,1 & 14,4 & 18,7 & 6,7 & 7,3 & 0,3 & 1,7 & $145,2(1)$ \\
\hline April & 12,1 & 11,0 & 13,8 & 8,6 & 4,6 & 27,2 & 2,5 & $33,9(2)$ \\
\hline Mei & 17,0 & 8,2 & 17,6 & 8,7 & 5,2 & 10,0 & 5,7 & $45,0(3)$ \\
\hline Juni & 8,0 & 10,5 & 9,8 & 7,7 & 10,9 & 24,4 & 5,8 & $71,7(3)$ \\
\hline Juli & 12,9 & 31,5 & 6,6 & 24,5 & 8,4 & 3,4 & 5,4 & $20,8(3)$ \\
\hline Agustus & 7,7 & 57,6 & 6,6 & 15,1 & 10,1 & 2,3 & 24,3 & $17,7(3)$ \\
\hline September & 6,7 & 47,8 & 46,0 & 28,0 & 11,4 & 6,5 & 18,2 & $28,5(3)$ \\
\hline Oktober & 4,2 & 51,9 & 15,0 & 43,3 & 21,0 & 3,9 & 38,2 & $49,7(3)$ \\
\hline Nopember & 9,1 & 56,1 & 8,3 & 6,8 & 11,4 & 0,9 & 34,9 & $23,6(3)$ \\
\hline Desember & 11,4 & 84,6 & 19,2 & 4,7 & 6,6 & 0,2 & 36,5 & $31,1(3)$ \\
\hline Kisaran & $4,2-17,0$ & $6,2-84,6$ & $6,6-46,0$ & $4,7-43,3$ & $1,0-21,0$ & $0,2-27,2$ & $1,3-38,6$ & $17,7-311,1$ \\
\hline Rata-rata & 10,4 & 32,8 & 16,2 & 14,8 & 8,7 & 7,2 & 14,8 & 75,4 \\
\hline
\end{tabular}

Tabel 2. Perkembangan beberapa jenis alat tangkap di Pelabuhanratu, tahun 1993 sampai dengan 2003

Table 2. The development of some types of fishing gear during, 1993 to 2003

\begin{tabular}{ccccc}
\hline Tahun & Payang & Gill net & Long line masuk & Long line keluar \\
\hline 1993 & 84 & 295 & - & - \\
1994 & 65 & 294 & - & - \\
1995 & 62 & 284 & - & - \\
1996 & 70 & 125 & - & - \\
1997 & 85 & 81 & - & - \\
1998 & 98 & 92 & - & - \\
1999 & 64 & 141 & - & - \\
2000 & 64 & 179 & $261(22)$ & nd \\
2001 & 65 & 168 & nd & $220(18)$ \\
2002 & 64 & 135 & $164(14)$ & \\
2003 & 84 & 151 & & \\
\hline Rata-rata & 73 & 177 & $-6,5 \%$ &
\end{tabular}

Utama yang berbasis di Benoa, Bali, memindahkan 10 kapal long line kelas 30 GT ke Pelabuhanratu. Jumlah kapal long line milik PT. Sari Samudera Utama akan terus bertambah mencapai 30 buah. Untuk memenuhi fasilitas-fasilitas penyimpanan tuna sebelum di ekspor, PT. Sari Segara Utama juga akan membangun sebuah coldstorage. Ini memudahkan untuk mengangkut ikan-ikan tuna yang diekspor ke bandara Soekarno-Hatta.

Perkembangan alat tangkap payang, gill net, dan long line yang menangkap tuna di
Pelabuhanratu disajikan dalam Tabel 2. Jumlah alat tangkap payang untuk menangkap tuna tidak banyak bervariasi, yaitu berkisar antara 62 sampai dengan 98 buah, sedangkan alat tangkap gill net terjadi penurunan rata-rata $6,5 \%$ per tahun. Kapalkapal tuna long line bulanan yang masuk Pelabuhan Perikanan Nusantara Pelabuhanratu dan produksi tahun 2003 disajikan dalam Tabel 3. Jumlah kapal long line yang mendaratkan hasil tangkapan pada tahun 2003 di Pelabuhanratu sangat berfluktuasi, yaitu berkisar antara 9 sampai dengan 27 kapal per bulan. Ini tergantung jauh 
Tabel 3. Jumlah kapal tuna long line yang masuk Pelabuhan Perikanan Nusantara Pelabuhanratu bulanan dan produksi tahun 2003

Table 3. Monthly number of tuna long line boats ( $>30$ GT) unloaded catch at Pelabuhan Perikanan Nusantara Pelabuhanratu in 2003

\begin{tabular}{lcclcc}
\hline \multicolumn{1}{c}{ Bulan } & Kapal masuk & Produksi (t) & Bulan & Kapal masuk & Produksi (t) \\
\hline Januari & 27 & 51,9 & Juli & 9 & 15,3 \\
Pebruari & 19 & 54,1 & Agustus & 4 & 7,5 \\
Maret & 20 & 76,3 & September & 8 & 17,8 \\
April & 11 & 30,0 & Oktober & 14 & 30,3 \\
Mei & 16 & 44,7 & Nopember & 7 & 18,1 \\
Juni & 20 & 77,1 & Desember & 9 & 26,5 \\
\hline & \multicolumn{7}{c}{ Total } & $\mathbf{4 4 9 , 4}$ \\
\hline
\end{tabular}

Sumber/Sources: - Pelabuhan Perikanan Nusantara Pelabuhan Ratu (Tahun 2004)

dekat beroperasi, apakah daerah penangkapan lebih dekat ke Pelabuhanratu, atau pelabuhanpelabuhan Iain (Pelabuhan Perikanan Samudera Jakarta atau Pelabuhan Perikanan Samudera Cilacap).

\section{Perkembangan Alat Tangkap Pancing Ulur}

Sejak tahun 2004 alat tangkap pancing ulur mulai beroperasi di perairan sebelah selatan Pelabuhan Ratu. Alat tangkap ini didatangkan dari Sulawesi Selatan oleh Koperasi Anak Nelayan sebagai perusahaan inti. Pada bulan Oktober 2004 , sudah ada 8 kapal yang beroperasi, dan sudah dipasang 3 buah rumpon. Rencana jumlah kapal yang didatangkan berjumlah 60 buah untuk beroperasi di Pelabuhan Ratu.

\section{Produksi}

Karena alat tangkap pancing ulur atau pancing layang-layang ini baru mulai beroperasi, maka data statistik hasil tangkapan belum tersedia secara lengkap. Produksi yang dikumpulkan pada bulan Pebruari, Maret, April, dan Mei 2005 disajikan dalam Tabel 4 . Kapal beroperasi dalam satu trip adalah 3 sampai dengan 4 hari.

Hasil tangkapan per kapal terus menurun sejak bulan Pebruari sampai dengan Mei 2005. Belum diketahui secara jelas, apakah penurunan ini karena musim atau tanda-tanda kelebihan upaya.

Tabel 4. Hasil tangkapan kapal-kapal pancing ulur di Pelabuhanratu

Table 4. Catch of hand line boats in Pelabuhanratu

\begin{tabular}{lccc}
\hline Bulan & Jumlah kapal & $\begin{array}{c}\text { Jumlah hasil } \\
(\mathbf{k g})\end{array}$ & $\begin{array}{c}\text { CPUE=kg per kapal } \\
\text { per trip }\end{array}$ \\
\hline Pebruari 2005 & 18 & 17.044 & 946,9 \\
Maret & 23 & 12.218 & 531,2 \\
April & 20 & 10.349 & 517,5 \\
Mei & 13 & 4.308 & 331,4 \\
\hline
\end{tabular}

Tabel 5. Komposisi hasil tangkapan pancing ulur dan pancing layang-layang di perairan Pelabuhanratu Table 5. Catch composition of hand line and pancing layang-layang in Pelabuhanratu waters

\begin{tabular}{|c|c|c|c|c|c|c|}
\hline \multirow{2}{*}{ Jenis ikan } & \multicolumn{6}{|c|}{ Hasil tangkapan per bulan (kg) } \\
\hline & Januari & Pebruari & Maret & April & Mei & Rata-rata \\
\hline Madidihang & $\begin{array}{c}4.058 \\
(46,6 \%)\end{array}$ & $\begin{array}{c}7.582 \\
(30,8 \%)\end{array}$ & $\begin{array}{c}10.743 \\
(46,6 \%)\end{array}$ & $\begin{array}{c}8.892 \\
(46,2 \%)\end{array}$ & $\begin{array}{c}7.084 \\
(49,3 \%)\end{array}$ & $\begin{array}{l}7.671,8 \\
(43,9 \%)\end{array}$ \\
\hline Cakalang & $\begin{array}{c}4.642 \\
(53,4 \%)\end{array}$ & $\begin{array}{c}17.044 \\
(69,2 \%)\end{array}$ & $\begin{array}{c}12.218 \\
(53,0 \%)\end{array}$ & $\begin{array}{c}10.349 \\
(53,8 \%)\end{array}$ & $\begin{array}{c}7.295 \\
(50,7 \%)\end{array}$ & $\begin{array}{l}10.309,6 \\
(56,02 \%)\end{array}$ \\
\hline Setuhuk biru & & & $\begin{array}{c}92 \\
(0,4 \%)\end{array}$ & & & \\
\hline Jumlah & 8.700 & 24.626 & 23.053 & 19.241 & 14.379 & \\
\hline
\end{tabular}




\section{Komposisi hasil tangkapan}

Komposisi hasil tangkapan yang dikumpulkan pada bulan Januari, Pebruari, Maret, April, dan Mei 2005 disajikan dalam Tabel 5. Hasil tangkapan didominansi oleh ikan cakalang kemudian madidihang, dan tercatat ada setuhuk biru yang tertangkap pada bulan Maret 2005. Hasil tangkapan didominansi oleh ikan cakalang. Hasil pengamatan menunjukkan bahwa dalam hasil tangkapan ikan-ikan madidihang yuwana dapat diidentifikasi ada ikan mata besar. Belum diketahui secara pasti bagaimana komposisi dari ke-2, tetapi kemungkinan persentase tuna mata besar jauh lebih kecil.

\section{Distribusi frekuensi panjang}

Distribusi frekuensi panjang cagak (fork length) dari ikan-ikan yang tertangap pada bulan-bulan Maret, April, dan Mei disajikan pada Gambar 3, a, b, dan c). Pada bulan Maret 2005 terlihat modus berada pada kelas panjang 45 sampai dengan 48 $\mathrm{cm}$, pada bulan April modus bertambah kecil, berada pada kelas panjang 41 sampai dengan 44 $\mathrm{cm}$ dan pada bulan Mei modus bertambah besar lagi dan kembali ke kelas panjang 45 sampai dengan $48 \mathrm{~cm}$. Kalau dibandingkan dengan panjang rata-rata, panjang rata-rata pada bulan April 2005 lebih besar daripada bulan Maret dan Mei 2005. Ini berlawanan dengan pergeseran

a

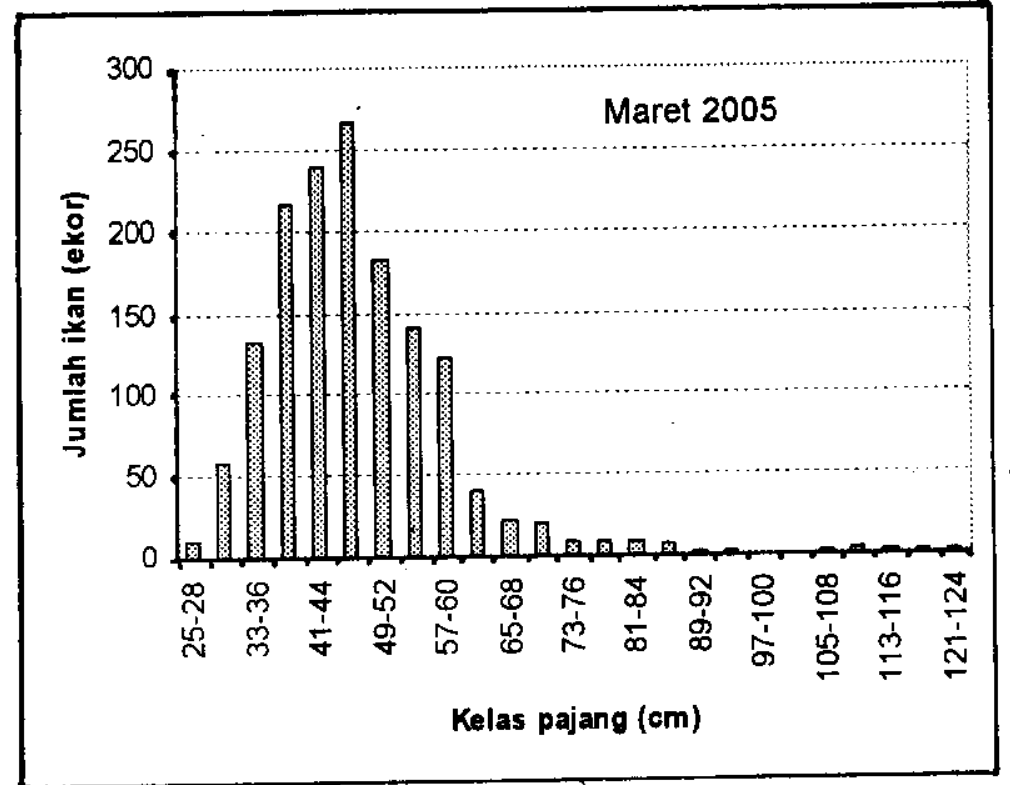

b

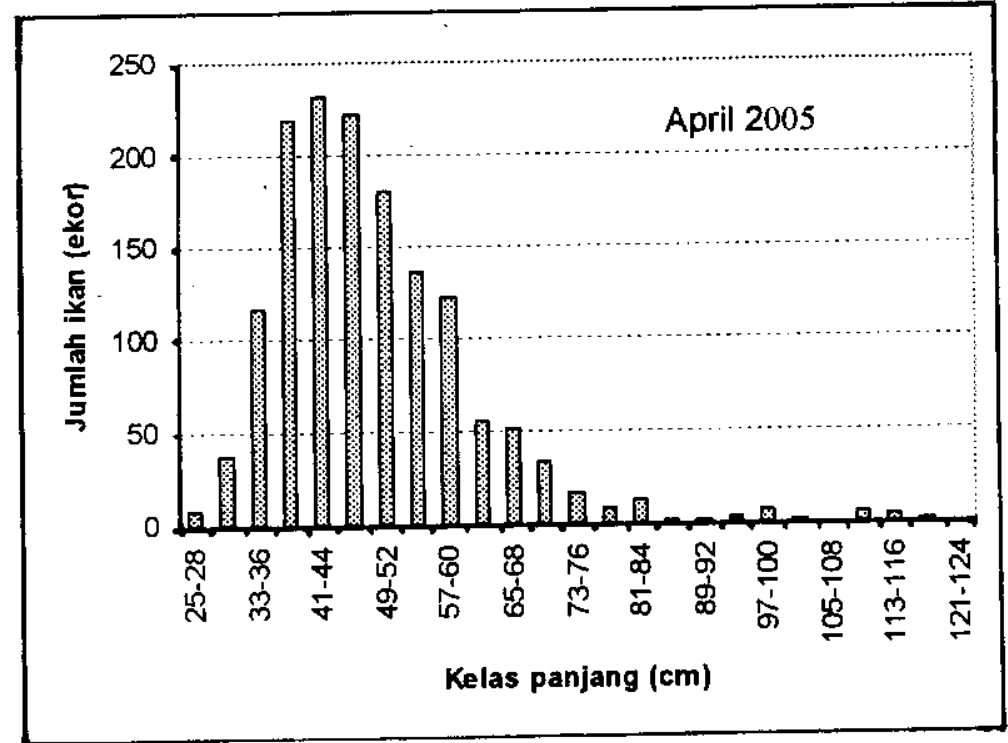




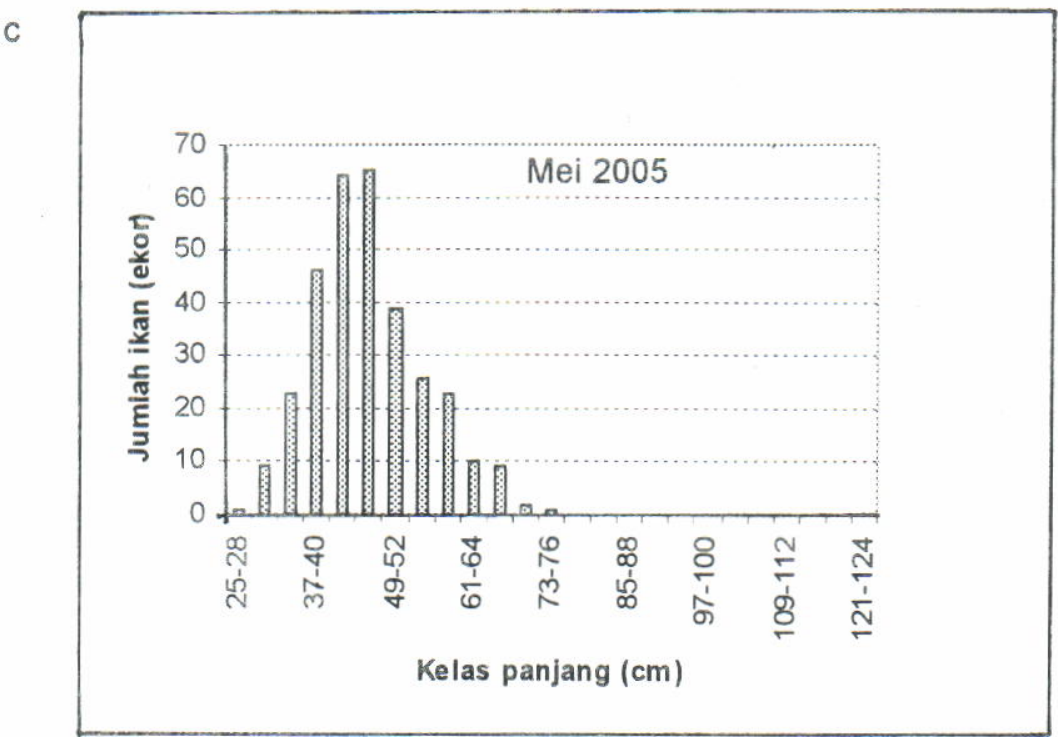

Gambar 3. Distribusi frekuensi panjang ikan madidihang yang tertangkap dengan pancing ulur di perairan sebelah selatan Pelabuhanratu pada bulan Maret, April, dan Mei 2005.

Figure 3. Length frequency distributions of yellow fin tuna (Thunnus albacares) caught by hand line in the waters south of Pelabuhanratu.

modus yang terjadi, yaitu ikan yang panjang ratarata terkecil tertangkap pada bulan Mei 2005 di mana modus terdapat pada kelas panjang 45 sampai dengan $48 \mathrm{~cm}$. Ini dapat dipahami karena panjang ikan yang tertangkap pada bulan Mei 2005 berkisar antara 28 sampai dengan $76 \mathrm{~cm}$, sedangkan pada bulan Maret dan April 2005 masing-masing berkisar antara 25 sampai dengan $123 \mathrm{~cm}$ dan 25 sampai dengan $119 \mathrm{~cm}$.

Ikan-ikan madidihang yang tertangkap pada umumnya yuwana, hanya sedikit sekali yang tertangkap sudah dewasa. Pengamatan yang dilakukan pada bulan Desember 2004, menunjukkan ikan-ikan madidihang (hanya madidihang) yang tertangkap dengan pancing ulur lebih besar, berkisar antara 15 sampai dengan 55 $\mathrm{kg}$ (Merta et al., 2005). Kalau kisaran bobot ini dikonversikan ke dalam panjang menggunakan hubungan panjang bobot yang diperoleh, menjadi 102,5 sampai dengan $156 \mathrm{~cm}$ FL. Untuk mengetahui apakah tuna rekrut ke perairan Pelabuhanratu dan sekitar pada bulan-bulan (paling tidak Maret, April, dan Mei), memerlukan penelitian lebih lanjut.

Beberapa studi menunjukkan bahwa ikan madidihang betina dapat mencapai kematangan berukuran terkecil $57 \mathrm{~cm} \mathrm{FL}$, tetapi data ini tidak didasarkan pada studi histologi. Ikan madidihang terkecil yang pernah diidentifikasi matang gonad dengan analisis histologi adalah $84 \mathrm{~cm} \mathrm{FL}$ dari perairan Pasifik tropis bagian timur. Studi-studi gonadosomatik untuk ikan-ikan yang tertangkap dengan alat tangkap long line menunjukkan bahwa sebagian besar ikan dalam perikanan long line mungkin tidak mencapai kematangan gonad sampai dengan mencapai panjang 110 sampai dengan $120 \mathrm{~cm}$ FL. Studi-studi histologi dari ikan madidihang dari Laut Coral bagian barat ditemukan $50 \%$ dari ikan madidihang yang diperiksa matang pada panjang $120 \mathrm{~cm}$ FL pada perikanan long line dan pada panjang $108 \mathrm{~cm}$ FL pada perikanan pancing ulur. Data di atas menunjukkan bahwa ikan madidihang pada perikanan permukaan adalah lebih banyak matang daripada perikanan long line. Lebih jauh diketahui bahwa ikan madidihang di perairan pantai dapat mencapai kematangan pada panjang rata-rata yang lebih kecil daripada ditempat lain (Western Pacific Yellow Fin Tuna Research Group, 1992).

Karena tidak diperoleh literatur mengenai ukuran panjang pertama kali matang gonad bagi ikan madidihang dari Samudera Hindia, maka dipakai asumsi dugaan bahwa ikan madidihang matang gonad pertama kali pada panjang $84 \mathrm{~cm} \mathrm{FL}$ (ikan-ikan $\geq 84 \mathrm{~cm}$ adalah dewasa dan $<84 \mathrm{~cm}$ adalah yuwana). Dari data frekuensi panjang bulanan yang dikumpulkan bararti pada bulan Maret ikan madidihang yang tertangkap $98,8 \%$, bulan April $98,2 \%$ dan bulan Mei seluruh (100\%) yuwana.

Ikan-ikan madidihang yuwana tertangkap bersama-sama dengan mata besar di sekitar rumpon. Pada waktu-waktu tertentu sangat melimpah. Kalau terus tertangkap tanpa terkendali 
dikhawatirkan akan mempengaruhi populasi, dan juga akan mempengaruhi produktivitas alat tangkap long line. Oleh karena itu, dalam pertemuan kelompok kerja tuna di Seychelles pada tahun 1998 dikeluarkan himbauan untuk menutup penangkapan di sekitar rumpon pada waktu ikan tuna mata besar yuwana melimpah. Himbauan tersebut telah dilaksanakan secara suka rela oleh asosiasi perusahaan yang menangkap ikan-ikan tuna di sekitar rumpon yang tersebar di perairan barat Laut Samudera Hindia, pada perairan $0^{\circ}-10^{\circ}$ $\mathrm{U} ; 45^{\circ}-70^{\circ} \mathrm{T}$, pada bulan-bulan Agustus sampai dengan Nopember. Moratorium ini belum memberikan pengaruh terhadap penangkapan ikan yuwana mata besar, karena mungkin waktu penutupan belum tepat (Romanov, 2000).

Moratorium yang di terapkan di Samudera Atlantik telah berhasil menurunkan mortalitas penangkapan yuwana ikan mata besar $45 \%$ untuk ikan-ikan yang baru rekrut, 30\% untuk ikan yang berumur 1 tahun dan $10 \%$ untuk ikan yang berumur 2 tahun (IOTC SECRETARY, 2000). Dalam jangka panjang, penutupan ini akan menaikkan nilai dugaan yield per rekrut.

\section{Hubungan panjang bobot}

Hasil analisis hubungan panjang bobot bulanan dari data ikan madidihang yang tertangkap dengan pancing ulur disajikan dalam Tabel 6.

Hasil uji-t terhadap nilai b, ternyata tidak berbeda dengan 3 baik untuk bulan Maret, April, maupun Mei 2005.

Hasil analisis hubungan panjang dan bobot yang diperoleh menunjukkan bahwa pola pertumbuhan ikan-ikan madidihang pada bulan Maret, April, maupun Mei 2005 yaitu tetap, isometris. Ini berarti bahwa pertumbuhan ikan madidihang dalam bobot sebanding dengan pangkat 3 panjang.

Penelitian-penelitian lain di Samudera Hindia menghasilkan hubungan panjang bobot yang berbeda-beda. Romanov (2000) memperoleh hubungan panjang bobot ikan madidihang sebagai berikut:

$$
W=3,111907^{\star} 10^{-5 *} L^{2.859513} \quad(n=16.240) \ldots \ldots . .(2
$$

Sedangkan Tantivala (2000) memperoleh hubungan panjang bobot ikan madidihang di Samudera Hindia bagian timur dengan nilai $b$ yang lebih kecil:

$$
W=0,000082^{\star} L 2.648 \quad(n=252 ; 35-83 F L) \ldots \ldots(3
$$

Perikanan tuna di Pelabuhanratu mempunyai prospek yang cukup baik dilihat dari fasilitas pelabuhan yang tersedia, Pelabuhanratu dekat dengan Muara Baru (Jakarta) dan juga dengan Bandara Cengkareng. Selama ini ikan-ikan tuna dari hasil tangkapan tuna long line di Cilacap dibawa ke Muara Baru dengan truk-truk kontainer berisi es. Perjalanan dari Cilacap ditempuh dalam waktu 7 sampai dengan 8 jam. Dengan mulai banyak pindah kapal-kapal tuna long line dari Cilacap ke Pelabuhanratu, maka transportasi yang dikeluarkan ke Jakarta menjadi lebih pendek dan biaya-biaya transportasipun menjadi lebih kecil.

Tabel 6. Hasil analisis hubungan panjang bobot ikan madidihang yang tertangkap dengan hand line di perairan selatan Pelabuhanratu

Table 6. The results of length weight analysis for yellow fin tuna caught by hand line in the waters

\begin{tabular}{|c|c|c|c|c|c|}
\hline Bulan & $n$ & a & b & $r$ & Keterangan \\
\hline Maret 2005 & 1.493 & 0,019394 & $3,016353^{\text {तह }}$ & 0,950577 & Isometris \\
\hline April 2005 & 1.478 & 0,015397 & $3,070463^{n s}$ & 0,951563 & Isometris \\
\hline Mei 2005 & 318 & 0,013780 & $3,107487^{\text {ns }}$ & 0,888769 & Isometris \\
\hline Gabungan & 3.289 & 0,011337 & $3,044603^{n s}$ & 0,946414 & Isometris \\
\hline
\end{tabular}
south of southeren Pelabuhanratu

\section{KESIMPULAN DAN SARAN}

\section{Kesimpulan}

1. Perikanan tuna di Pelabuhanratu akan terus berkembang dengan ada fasilitas pelabuhan yang memadai, serta jarak yang dekat dengan Jakarta dan Bandara Soekarno-Hatta.
2. Pada bulan-bulan tertentu yuwana madidihang tertangkap cukup melimpah, rata-rata 99,0\% (dalam periode Maret, April, dan Mei 2005).

3. Hubungan panjang bobot ikan-ikan madidihang yang tertangkap adalah isometris. 


\section{Rekomendasi}

1. Pengembangan lebih lanjut perikanan tuna di Pelabuhanratu, perlu kehati-hatian, mengingat melimpahnya ikan-ikan yuwana madidihang dan kemungkinan juga yuwana mata besar yang tertangkap pada bulan-bulan tertentu.

2. Perlu dilakukan penelitian yang lebih komprehensif untuk mengantisipasi perkembangan perikanan tuna di Pelabuhanratu, karena banyak tertangkap jkanikan tuna yuwana pada bulan-bulan tertentu.

\section{DAFTAR PUSTAKA}

Barus, H. R. \& M. Badrudin. 1992. Penangkapan ikan tuna dan cakalangdengan pancing ulur di perairan Maumere, Laut Flores. Jurnal Penelitian Perikanan Laut. (66): 53-60.

Batubara, H. M. P. 2004. Keragaan usaha dan perkembangan produktivitas penangkapan tuna PT. Perikanan Samodera Besar. Makalah yang disajikan dalam Lokakarya Evaluasi Peluang Invetasi Usaha Penangkapan Tuna. Jakarta. 14 September 2004. 20 hal.

Hayasi, S. 1971. Stock assessment. IOFC/DEV/71/3. 34

IOTC SECRETARY. 2000. Time and area closure of the fishery on floating objects. IOTC Seychelles. 8 p.

Klawe, W. L. 1980. Long line catches of tunas within the 200 mile Economic Zones of the Indian and Western Pacific Oceans. Dev. Rept. Indian Ocean Programme. (48): 83 p.

LeCren, E. D. 1951. The length weight relationships and seasonal cycle in weight and condition in the perch (Perca fluviatilis). Journal Anim. Ecological. 20 (2): 201-219.

Merta, I G. S., K. Susanto, \& B. I. Prisantoso. 2003. Pengkajian stok di Samudera Hindia (wilayah pengelolaan perikanan 4). Dalam Prosiding Forum Pengkajian Stok Ikan Laut 2003. (wilayah pengelolaan perikanan: Samudera Hindia, Laut Arafura, Laut Cina Selatan, dan Laut Jawa). Pusat Riset Perikanan Tangkap. Badan Riset Kelautan dan Perikanan. Departemen Kelautan dan Perikanan. Jakarta. 23-24 Juli 2003. Hal 13-29.
Merta, I G. S., C. Proctor, \& S. Fujiwara: 2005 Report on tuna fisheries in Pelabuhan Ratu. based on fact finding survey on Dec. 1-3. 2004. Draft. $5 \mathrm{p}$.

Marcille, J., T. Boely, M. Unar, I G. S. Merta, B. Sadhotomo, \& J. C. B. Uktolseja. 1984. Tuna fishing in Indonesia. ORSTOM Document No.181. Paris.

Mauck, P. E. \& R. C. Summerfelt. 1970. Length weight relationships, age composition, growth, and condition factors of carp in Lake Blackwell. Procidding Okla. Acad. Scie. 50: 61-68.

Nashrullah, A. 2005. Studi perkembangan perikanan dan dan beberapa aspek biologi ikan madidihang (Thunnus albacares) hasil tangkapan pancing di perairan sebelah selatan Teluk Pelabuhan Ratu. KIPA Jur. TPS. Sekolah Tinggi Perikanan. Jakarta. 108 hal.

Pelabuhan Perikanan Nusantara Pelabuhan Ratu 1993-2003. Statistik perikanan tahun 19982004.

Proctor, C. H., I G. S. Merta, M. F. A. Sondita, R. I. Wahyu, T. L. O. Davis, J. S. Gunn, \& R. Andamari. 2004. A Review of Indonesia's Indian Ocean Tuna Fisheries. Country Status Report. ACIAR. Departemen Kelautan dan Perikanan. CSIRO and Institut Pertanian Bogor. 106 p.

Ramakrishnaiah, M. 1972. Biology of Hilsa llisha (Hamilton) from the Chilka Lake with an account on its racial status. Indian Journal Fisheries. 19 (1 and 2): 35-53.

Romanov, E. V. 2000. By catch in the Sovyet purse seine tuna fisheries on FAD-associated schools in North Equatorial Area of the western Indian Ocean. IOTCNWPTT/00/31. 21 p.

Simorangkir, S. 2000. Southern blue fin tuna dalam tangkapan kapal tuna long line yang berpangkalan di Pelabuhan Benoa, Bali. Indonesia-Australia worksop on shark and tuna. Future collaboration on developing research capacity to support the development of fisheries management. Denpasar, Bali, 1-3 March 2000. 9 p.

2003. Status perikanan tuna nasional. Makalah disajikan pada Lokakarya Pengkajian Stok Sumber Daya Ikan Nasional. Jakarta. 25 Maret 2003. 
Tantivala, Ch. 2000. Some biological study of yellow fin tuna (Thunnus albacares) and big eye tuna (Thunnus obesus) on the eastern Indian Ocean. WPTT/00/30. 10 p.
Western Pacific Yellow Fin Tuna Research Group. 1992. Report of the second meeting of the Western Pacific yellow fin tuna research Group. Honolulu. Hawaii. 79 p. 
